\title{
The International Institute of Islamic Thought Intellectual Panels
}

The International Institute of Islamic Thought (IIIT) held a series of panels at the 41 st annual convention of the Islamic Circle of North America (ICNA) in Baltimore, MD, on Sunday, May 29, 2016.

The first panel, "Maqāṣid al-Sharī'ah as a Philosophy of Islamic Law," featured Jasser Auda (Al-Shatibi Chair of Maqasid Studies, the International Peace College, South Africa) and Ebrahim Rasool (Distinguished Scholar in Residence at Georgetown University's Edmund A. Walsh School for Foreign Service and former ambassador of South Africa to the U.S.), with Ermin Sinanović (director, Research and Academic Programs, IIIT) as moderator.

Sinanović began by introducing IIIT to the diverse audience. He explained that the institute is devoted to the revival of Islamic traditions and the reform of Muslim societies. In addition to affirming that our sources and principles are unchangeable, he positioned IIIT as the institution dedicated to making our 
intellectual legacy the core of the solution to our current malaise, for it is the "answer to the crisis of the ummah," a crisis that is largely intellectual in nature: our inability to translate our eternal message as per our time and space.

The lineup of IIIT panels certainly reflected the institute's commitment to addressing contemporary issues in an intellectual manner. The large numbers of attendees at each panel showed the thirst people have for solutions rooted in our sources and traditions that go beyond literalistic interpretations.

The Maqāșid al-Sharī'ah panel especially resonated with the audience, as it focused on taking into account the higher objectives of the Shari'ah as opposed to treating it as a list of do's and don'ts. Auda acknowledged the support and strategic vision of the late Jamal Barzinji when he showed him the manuscript of his book, Maqāsidid al-Sharī'ah as Philosophy of Islamic Law: A Systems Approach (Herndon, VA: IIIT, 2008).

Defining maquassid as the objective, reason, and the "why" for all concerns under Shari'ah, he called this approach an "entry point for Islamic thought for a lot of issues," and hopes that it will soon become a discipline and be taught at universities. "When we deal with current problems only with figh, we miss the mark. There is no depth and our approach is not fulfilling," he stated. He said that it is time we bring "fiqh Islāmi (Islamic jurisprudence) to fikr Islāmī (Islamic thought)." At the same time, he cautioned against using the maqāssid to justify un-Islamic practices as a purported consequence of hifz al-nafs.

He summed up his talk by clarifying that the maqāșid do not replace uṣūl al-fiqh (the principles of jurisprudence); rather, they must be applied with the spirit of the maqāșid al-Sharī 'ah, "otherwise we will be literalists." As such, they are a "window to renewal." At the end of the panel, he signed copies of his book for audience members.

Next, Rasool spoke of the Qur'an as a "healing and mercy" from Allah (Q. 17:82) and decried our utilitarian approach to it. "We treat the Qur'an like a supermarket and take what we want from it, much like ISIS," he exclaimed. He recalled such cherry-picking during the anti-apartheid struggle in South Africa: "The ulema who cautioned us against it, we dismissed them," he said. However, when he was arrested on June 6, 1987, his transformation began. He spent six months in solitary confinement and was only allowed to have the Qur'an. "It became my protection against insanity and prevented me from breaking down in front of my interrogators," he reminisced.

"At first, I went to the Qur'an for my favorite verses," Rasool recollected. Eventually, with the Qur'an as his sole companion, he undertook a systematic reading, varying his day between reciting, reading the translation, memorizing, reflecting, and indexing the Qur'an. 'In doing so, I found more purpose, less 
utility, and became less self-indulgent," he remarked. "When you see only rules and regulations, you only see your own victimhood, not the larger, more meaningful connections. ... The very fact that the Qur'an has so many parables goes against our literalist reading!" He concluded by asserting that when we adopt the maqāsid approach, it speaks to our fitrah and the Qur'an truly becomes a healing and mercy.

IIIT's second panel, "Islamophobia: Root Causes, Effective Solutions," featured Mohamed Nimer (assistant professor, American University), Ambassador Ebrahim Rasool, and Engy Abdelkader (professor, Edmund A. Walsh School of Foreign Service, Georgetown University). Zahid Bukhari (director, American Muslim Studies Program; fellow, Center for Muslim-Christian Understanding at Georgetown University) moderated.

Nimer, author of Islamophobia and Anti-Americanism: Causes and Remedies (Brentwood, MD: amana publications, 2007), drew a distinction between cultural Islamophobia and political Islamophobia. Cultural Islamophobia is the general fear held by many non-Muslims of Islam and Muslims due to their lack of knowledge, whereas political Islamophobia uses the former for political gain, recognizing that anti-Muslim rhetoric can translate into votes. He cited Donald Trump as the "quintessential manipulator of Islamophobia for political gain" and recommended more dialogue and less condemnation.

Rasool contended that Islamophobia is part of a lineage that includes racism, sexism, and xenophobia. He suggested that we must comprehend what we are dealing with, understand that we are victims without internalizing victimhood, and recognize that there is a clear and present danger as we stand on the eve of the institutionalization of Islamophobia. Moreover, we must awaken our own agency so that we can make broad alliances, like the Hilf al-Fudul, based upon common cause and trust. "The best way to fight Islamophobia is to fight racism. Fight the whole evil family, not just one evil sibling," he said.

Abdelkader, an award-winning attorney and assistant director of Georgetown's Bridge Initiative, shared that this initiative is focused on researching Islamophobia and connecting it with the public square. She stressed that the misinformation and stereotypes that feed Islamophobia must be undermined by scholarly research and made accessible to the lay people. In her opinion, the root causes of Islamophobia are the result of military intervention, which casts Muslims as the potential enemy, coverage of Muslims in the media as overwhelmingly about violence, and anti-Muslim political rhetoric.

During 2015, the Bridge Initiative recorded 174 acts or threats of violence against Muslims, compared to 154 hate crimes recorded by the FBI in 2014. Surges in the 2015 figures ran parallel to former Republican presidential can- 
didate Ben Carson's claim that Muslims cannot hold the presidential office, unflattering coverage of the Syrian refugee crisis in The New York Times, and Trump's anti-Muslim comments in the wake of the Paris attacks. In the last instance, hate crimes tripled, with half of them targeting mosques. "As Trump [verbally] attacked mosques, there were physical attacks on mosques," Abdelkader specified. One-third of all violent attacks during 2015 took place in December, which experienced a five-fold increase, possibly as a consequence of the San Bernardino attacks, coverage, and resulting political rhetoric.

In a study undertaken by Abdelkader, she found that the amount of verbal abuse endured by Muslims is comparable between men and women. However, Muslim men are far more susceptible to violent attacks and are eleven times more likely than women to be murdered. She admitted that this statistic surprised her, since Muslim women are generally considered more vulnerable to hate due to wearing the hijab or similar attire. Nevertheless, Abdelkader ended her talk on a high note, praising regular American Muslims for standing up and asking candidates about countering Islamophobia. She said, "They are not activists, they are not trained, but they know something needs to be done!"

Bukhari (executive director, Center for Islam and Public Policy) discussed the recently formed US Council of Muslim Organizations and its threepronged approach based on unity, engagement, and communication. He invited all Muslim organizations to join it so that American Muslims have a united platform, even as individual groups continue to work on their own mandates. He outlined four types of engagement: participation, alliances, open houses, and social services. In addition, he spoke about the One America Campaign, which aims to register one million voters prior to the 2016 presidential election regardless of race, ethnicity, and religion. Moreover, they seek to create local and national alliances; host a National Open Mosque Day on October 16; and continue to address the needs of the American people whether in terms of feeding the hungry, empowering the homeless, or providing support in times of national disasters.

Bukhari also stressed the importance of communication and stated that material will be made available in various languages for broad propagation. He mentioned the 130 billboards that ICNA sponsored in 2015, which received positive media coverage.

The third and last panel, "Mind the Gap: Bringing Islamic Scholars and Scientists Together," included Sheikh Jihad Brown, Aasim Padela, and Maulana Bilal Ali, and was moderated by Sinanović.

Jihad Brown, who has studied Arabic rhetoric, dialectic theology, and Islamic legal theory with prominent religious authorities in Damascus, began 
his presentation by sketching the current situation where the language of compassion and $i h s a \bar{a} n$ (striving toward personal excellence) is increasingly becoming foreign, only spoken by the brave. Yet "the outside world is quickly becoming our community, and religion is not about shunning the world." $\mathrm{He}$ cited the hadith, "Fear the prayer of the oppressed, even if not a Muslim," to highlight the need for Muslims to be aware of their actions. In conclusion, he advised them to replace their sentimental sense of identity with a more effective, substantive identity in order to acquire "more far-sighted objectives which will be inclusive of everything we want to achieve."

Padela (director, Initiative on Islam and Medicine; assistant professor of Medicine in the Section of Emergency Medicine; faculty member, MacLean Center for Clinical Medical Ethics) asked the audience "to move beyond a static view of the world." Speaking directly to the lack of interaction between theologians and medical professionals, he illustrated the subsequent elementary perceptions that lead to simplistic views, causing confusion among ordinary people. In the case of organ donation, Padela stated that medical professionals will look to the fiqhi position, find that many fatwas consider it to be permissible from a mașlahah perspective, and then tell them to go ahead. However, from a bioethics standpoint it is a far more complex issue, one that gets eclipsed due to the fact that "medical doctors are divorced from the fiqhi understandings and vice versa," he maintained. He stressed the need to bring both camps together for more holistic discussions.

Ansari, president of the faith-based Khalil Center's board and a key strategic advisor to the organization, talked about his involvement with the center, which tackles mental health from a spiritual wellness viewpoint. "We explore how an understanding of spirituality can inform psychological treatment," he explained. Ansari is well-versed in traditional Islamic studies and holds a degree in applied behavioral sciences. His research interests include Hadith, Hanafi law, education and curriculum development, mental health, and Islamic bioethics. The Khalil Center offers many services, such as therapy sessions, workshops, pre-marital coaching, and access to Shari'ah consultants. Based upon his experience with the center, he emphasized the importance of collaboration between mental health officials and Islamic legal experts.

Each panel was followed by a vibrant Question and Answer session, enabling audience members to engage with the panelists. 